\title{
HUMAN RIGHTS PROVISIONS IN GENERAL CORPORATE LENDING
}

How banks could implement their responsibility to respect human rights by including human rights provisions in corporate lending documentation.

Wilke de Boer \& Martijn Scheltema ${ }^{1}$

\section{TABLE OF CONTENT}

\section{Introduction}

\section{Why banks care about human rights}

2.1. Human rights violations pose commercial risks to banks

2.2. Banks have a responsibility to respect human rights

2.3. Banks face a legal duty to respect human rights

2.4. Focus on human rights due diligence in corporate lending

3. How contractual provisions could support human rights due diligence

3.1. Human rights due diligence

3.2. 'Leverage' through contract

3.3. Current practice of contractual provisions in project finance and asset based finance

3.4. Current practice of contractual provisions in corporate lending

4. Why banks are hesitant to include human rights provisions in loan documentation

4.1. Human rights performance is hard to measure

4.2. Principle based language is not suitable for loan documentation

4.3. Lack of consensus and urgency

4.4. Leverage poses a challenge in syndicates

5. The potential of sustainability linked loans in the area of human rights

5.1. The rise of sustainability linked loans

5.2. Human rights focused sustainability performance targets

6. A global standard on human rights provisions in corporate lending

6.1. Importance of a level playing field: recommendations

7. Practical guidance for human rights provisions

\section{Conclusion}

\footnotetext{
${ }^{1}$ Wilke de Boer currently works as legal counsel sustainable finance at NWB Bank and was, at the time of writing, working for the Social-Economic Council of the Netherlands on the Dutch International Responsible Business Conduct Agreement in the banking sector. Martijn Scheltema is professor at Erasmus University Rotterdam, partner/chair of the business human rights practice group of Pels Rijcken (a Dutch law firm) and chair of the binding dispute resolution mechanism of the Dutch International Responsible Business Conduct Agreement in the Textile sector. Authors declare no conflicts of interest in connection with this article.
} 


\section{Introduction}

Evidently, sustainability is a burning issue in current society and politics. It is genuinely understood that the term sustainability can be broken down into three pillars: economic, environmental and social. Similar terms used are "people, planet and profit". Between the environmental and social pillar, the former has been a priority on the financial sector's agenda in the recent years. The focus of this article however will be on the social pillar: the enjoyment of human rights while carrying out business activities.

More specifically, we will focus on the role of banks in the area of human rights and corporate lending. We will argue that it is in the interest of banks to manage human rights risks from a legal, commercial and ethical perspective. We will explain how contractual provisions can play an important role in carrying out 'human rights due diligence' by banks. We argue that banks can exercise leverage over their clients by including provisions on human rights in loan documentation. Banks could hereby build on the emerging practice of the "sustainability linked loans", whereby clients enjoy commercial benefits when predetermined sustainability targets are met. We argue that in order to negotiate human rights focused targets and requirements, an international level playing field on human rights needs to be created on the international corporate lending market. The creation of such level playing field can be accelerated if human rights provisions find their way into standard loan market documentation. This may also enhance the attention paid to this topic within companies and reflects the growing maturity of it. We conclude this article with providing practical guidance for negotiating human rights provisions in loan agreements, based on the language and structure of the LMA Investment Grade Agreement. 


\section{Why banks care about human rights}

\subsection{Human rights violations pose commercial risks to banks}

In the business model of banks, providing loans is one of the principle ways to earn money. When providing loans, banks charge interest over the loan until the total loan is repaid by the client. Traditionally, the first and paramount risk of banks is that clients will not be able to repay the loan. Therefore, assessing the creditworthiness of clients and projects is an important element in a bank's lending practice. That is why banks conduct 'due diligence' prior and during the term of the loan.

In recent years, another type of risk has emerged that could negatively affect bank's loan portfolios: human rights risks. While human rights impacts primarily pose risks to third parties that are affected, they may eventually establish a reputational, legal and financial risk to the bank. A well-known example is the Agua Zarca Hydro Project in Honduras, financed by two development banks. The project infringed indigenous people rights and eventually led to the murder of a human rights defender. While both banks terminated the loan in 2017, a lawsuit is currently pending against one of the banks arguing that it violated its duty of care. Another recent example is the Dakota Access Pipeline, a US pipeline running through Native American grounds and violating indigenous people lands and waters. A Dutch bank was one of the lenders financing the project and another Dutch bank financed a parent company of a constructing company. Both banks were under great public scrutiny and were eventually compelled to divest.

These examples clarify that human rights violations have to be taken seriously by banks. They can pose three types of commercial risk to banks: reputational, legal and financial risks.

\section{- Reputation risk}

From a reputational risk point of view, societal trust in the banking sector currently is rather low and actions of banks are scrutinized. In this critical environment, banks should not be connected to human rights violations, either through their own activities or through activities of their clients. In fact, integrating respect for human rights into bank policies and procedures should be considered as an opportunity to regain public trust and to become future proof.

\section{- Legal risk}

From a legal risk point of view, stakeholders are increasingly embarking in lawsuits and nonjudicial mechanisms (such as the OECD National Contact Points) against banks based on environmental and social grievances. ${ }^{2}$ Furthermore, governments are increasingly adopting legislation that requires enterprises including banks to do business with respect for human rights.

\section{- Financial risk}

\footnotetext{
2 Non-judicial cases (against banks): (ING) http://mneguidelines.oecd.org/database/instances/nl0029.htm, (Crédit Suisse) http://mneguidelines.oecd.org/database/instances/ch0016.htm, (Rabobank) http://mneguidelines.oecd.org/database/instances/nl0024.htm.

Judicial cases (against banks and non-banks): (FMO) https://www.theguardian.com/globaldevelopment/2018/may/18/bank-faces-lawsuit-over-honduras-dam-project-spirit-of-berta-caceres-fmoagua-zarca, (Dutch State) https://www.rechtspraak.nl/Uitspraken-en-nieuws/Bekenderechtszaken/klimaatzaak-urgenda, (Shell) https://www.theguardian.com/globaldevelopment/2019/feb/12/ogoni-widows-testify-the-hague-shell-alleged-complicity-killings
} 
Thirdly, human rights violations could evolve into financial risk. Damages on client level - e.g. costs resulting from litigation or related to delays or withdrawal from projects ${ }^{3}-$ lead to an increased risk profile of the client during the term of the loan.

\subsection{Banks have a responsibility to respect human rights}

Apart from a commercial interest to respect human rights, banks have a responsibility to respect human rights under international (soft) law. This article focuses on two international authoritative frameworks for business and human rights: the UN Guiding Principles on Business and Human Rights ("UNGPs") and the OECD Guidelines for Multinational Enterprises ("OECD Guidelines"). ${ }^{4}$ These frameworks expect enterprises to respect human rights and to address human rights risks in their global operations by conducting 'human rights due diligence'. ${ }^{5}$ Due to the broad definitions of 'multinational enterprise' and 'business enterprise', these frameworks apply to banks active on the international loan market. Most Dutch banks have endorsed the OECD Guidelines and UNGPs through their (sustainability) policies. Internationally, banks have started working together on the interpretation and application of these guidelines in order to meet their individual responsibility to respect human rights. ${ }^{6}$

\subsection{Banks face a legal duty to respect human rights}

Although not legally binding, the UNGPs and OECD Guidelines are regarded as the global authoritative standards on responsible business conduct and have the potential to influence the evolution of hard law. ${ }^{7}$ The legal landscape relating to business and human rights is slowly shifting from international non-legally binding frameworks to legally binding national legislation. Over the past few years, the concept of chain responsibility and human rights due diligence has been adopted in national legislation. In 2014, the EU directive on non-financial reporting entered into force. The directive was implemented in the Dutch Civil Code in 2016 and requires large public interest companies - including banks - to report on human rights risks, policies (including due diligence processes) and management. With regard to human rights policies and due diligence, legislation adopted a 'comply or explain' approach. ${ }^{8}$ In 2015 , the UK adopted legislation requiring eligible (larger) companies to which the law applies to disclose their efforts to eliminate human trafficking and slavery from their supply chains. ${ }^{9}$ Similar legislation has been adopted in Australia and is being considered in Hong Kong. ${ }^{10}$ In 2017, France adopted legislation requiring certain companies to conduct due diligence in their supply chains in relation to human

\footnotetext{
${ }^{3}$ For example, $40 \%$ of the mining projects in Peru is delayed or cancelled because of human rights issues resulting in an overall damage of $\$ 21$ billion (see: http://www.mining.com/over-21bn-worth-of-miningprojects-delayed-in-peru-due-to-social-conflict/ and McKinsey, An Assessment of the Competitiveness and Health of the Peru's Mining Industry, May 2013, p. 38-40)

${ }^{4}$ http://www.oecd.org/daf/inv/mne/48004323.pdf and https://www.ohchr.org/Documents/Publications/GuidingPrinciplesBusinessHR_EN.pdf

${ }^{5}$ The UNGPs do not steak of risks but "impacts", through their "risk to people" lense.

${ }^{6}$ https://www.businesshumanrights.org/sites/default/files/Thun\%20Group\%20of\%20Banks_description_final.pdf

7 Banks and human rights, a legal analysis, Foley Hoag LLP and the UNEPFI, December 2015, p. 4 and 6.

${ }^{8}$ Art. 2:391 section 5 Dutch Civil Code and 'Besluit bekendmaking niet-financiële informatie' dated 14 March 2017

9 UK Modern Slavery Act 2015: http://www.legislation.gov.uk/ukpga/2015/30/contents/enacted

${ }^{10}$ Australian Modern Slavery Act 2018: https://www.aph.gov.au/Parliamentary_Business/Bills_Legislation/Bills_Search_Results/Result?bId=r6148.
} 
rights, environmental and health and safety issues. ${ }^{11}$ In May this year, the Dutch Senate voted to adopt a law introducing a duty of care to prevent child labour for companies selling goods and services to Dutch end-users. ${ }^{12}$ Several other European countries are also considering legislation requiring companies to conduct social and/or environmental due diligence. Considering these national initiatives, we feel harmonized legislation on EU level is preferable to avoid a sprawl of different national legislative measures with diverging standards. We expect EU legislation with human rights due diligence standards governing business enterprises in EU member states to be adopted in the near future. This type of legislation is already adopted in connection with conflict minerals that are imported in the EU and will come into force on January $12021 .{ }^{13}$ Hence, banks are advised to take a forward-looking approach and anticipate on legislation on human rights due diligence.

\subsection{Focus on human rights due diligence in corporate lending}

In short, human rights due diligence requires banks to identify and assess human rights risks, to act upon findings, to track whether their responses are effective and to communicate about this process externally. ${ }^{14}$ As we will elaborate hereunder, contractual provisions can play an important role in conducting human rights due diligence for banks' lending activities. In the field of project finance, the use of contractual provisions to address human rights risks to date is quite common. In the field of corporate lending however, banks are generally not implementing contractual provisions to address human rights risks. This article will further explore how contractual provisions may strengthen bank's human rights due diligence in their corporate lending practice.

\section{How contractual provisions could support human rights due diligence}

\subsection{Human rights due diligence}

One of the innovative features of the UNGPs was the introduction of 'human rights due diligence', meaning that business enterprises are expected to conduct due diligence in order to identify, prevent, mitigate and account for human rights risks related to their own activities or through their business relationships. ${ }^{15}$ The 2011 revision of the OECD Guidelines has further harmonized the international human rights arena by aligning these guidelines with the human rights framework of the UNGPs and incorporating the concept of human rights due diligence. The introduction of the UNGPs in 2011 and the revision of the OECD Guidelines may be considered a response to globalisation. In the process of globalisation, national corporations have developed into large multinational enterprises with extensive international corporate structures and huge economic power. Some multinational enterprises are even considered more powerful than

\footnotetext{
${ }^{11}$ French law on corporate duty of vigilance 2017 :

https://www.legifrance.gouv.fr/affichTexte.do?cidTexte=JORFTEXT000034290626\&categorieLien=id

12 https://www.eerstekamer.nl/verslagdeel/20190514/wet_zorgplicht_kinderarbeid

13 Regulation EU 2017/821, which can be accessed through https://publications.europa.eu/en/publicationdetail/-/publication/8b0e378b-3c59-11e7-a08e-01aa75ed71a1/language-en/format-PDFA1A. This legislation builds on the the OECD Due Diligence Guidance for Responsible Supply Chains of Minerals from ConflictAffected and High-Risk Areas, to be found at https://www.oecd.org/corporate/mne/GuidanceEdition2.pdf.

14 Principles 18 to 21 of the UNGPs.

15 GP 17: Instead of referring to human rights "risks", the UNGPs use the terminology "adverse human rights impacts"
} 
smaller national economies. As power and influence comes with responsibility, an increasing societal expectation has emerged that business enterprises should be held accountable for negative environmental and social impacts because of their global activities. ${ }^{16}$ The UNGPs and the 2011 revision of the OECD Guidelines have contributed to this concept of accountability for global activity of enterprises.

\section{2. 'Leverage' through contract}

When conducting human rights due diligence in connection with their lending operations, banks may find adverse human rights impacts. According to the UNGPs, banks should take 'appropriate action' once an adverse human rights impact has been identified. What constitutes appropriate action depends on two factors, one of which is a banks 'leverage' in addressing the impact. ${ }^{17}$ Leverage is considered to exist where the bank has the ability to effect change in the wrongful practices of an entity (e.g. a bank's client) causing or contributing to the harm. According to the UNGPs, contractual provisions can play an important role in exercising leverage in business relationships. ${ }^{18}$ If we apply this to lending practices of banks, this implies that banks can exercise leverage over clients by including provisions on human rights in loan documentation. Having said this, it is important to keep in mind that banks cannot comply with their responsibly to respect human rights by solely including provisions in loan documentation. However, including human rights related provisions in loan documentation can be an innovative, creative and necessary way to exercise or increase leverage on a bank's client.

\subsection{Current practice of contractual provisions in project finance and asset based finance}

Incorporating sustainability related provisions in loan documentation is far from an entirely new phenomenon. In project finance and asset-based finance, banks are currently using frameworks that provide guidance on incorporating sustainability related provisions in loan documentation.

\section{- Equator Principles}

A well-known example are the Equator Principles (EP), applicable to project finance and project related loans and services. The EP are a risk management framework for determining, assessing and managing environmental and social risk in projects and provide banks with a minimum standard for due diligence and monitoring. EP signatories will not provide financing to EP projects if the borrower cannot or will not comply with the EP. Thus, the EP constitute a strong tool to incentivize leverage by EP signatories. In the 2013 revision of the EPs, the UNGPs were integrated requiring banks to complement the EP environmental and social impact assessment (ESIA) with specific human rights due diligence in designated projects. It is expected that the forthcoming EP4 will further strengthen the human rights focus of the EP. ${ }^{19}$ EP 8 is key when considering the contractual leverage of EP banks. EP 8 requires the inclusion of 'covenants' into

\footnotetext{
${ }^{16}$ Freshfields Bruckhaus Deringer, Five trends to watch Business and Human Rights, March 2018, p. 4

17 Principle 19 (b) of the UNGPs. The other factor is whether the bank "causes", "contributes to" or is "directly linked" to the adverse human rights impact. In this article, we are focussing on the leverage element.

18 UNGP Interpretative Guide, p. 48.

19 The EP Association is currently undertaking a review of the Equator Principles. The fourth version of the Equator Principles (EP4) is expected to be available by the end of 2019. https://equator-principles.com/wpcontent/uploads/2019/07/Summary-of-proposed-changes-in-EP4-09-07-19.pdf
} 
legal documentation structuring the deal. ${ }^{20}$ Covenants are promises made by the borrower to undertake certain actions (positive covenants) or to refrain from taking certain actions (negative covenants). For all EP projects, the client will covenant to comply with all relevant host country environmental and social laws, regulations and permits in all material respects. For higher risk EP projects, ${ }^{21}$ clients additionally covenant (i) to comply with environmental and social management plans or action plans, (ii) to provide periodic environmental and social compliance reports and (iii) to decommission in accordance with a decommissioning plan. ${ }^{22}$ Besides covenants, so called 'conditions precedent' and 'representations and warranties' may be included in the loan documentation..$^{23}$ If the borrower breaches a covenant, representation or warranty this may depending on the triggers in the loan documentation - constitute an event of default meaning that the borrower has to repay the loan.

\section{- Responsible Ship Recycling Standards}

In 2012, the Dutch Fair Finance Guide published a report about the alarming working conditions on and pollution from ship breaking yards in Asia and the connected ship financing practices of banks. Recognizing that ship-recycling practices can have environmental and social consequences, ABN Amro, NIBC and ING announced the Responsible Ship Recycling Standards (RSRS) in 2017. To date, seven of the top financiers of ships have committed to RSRS. By becoming a signatory to the RSRS, banks recognize that ship recycling is part of the shipping industry value chain and commit to implement the RSRS into their environmental and social policies, procedures and standards for the financing of shipping assets on a best effort basis. ${ }^{24}$ Pursuant to the RSRS the loan agreement provides an opportunity to require a borrower to meet the relevant ship recycling standards. Similar to the EPs, the RSRS provide language that may be included in the loan documentation as covenants or conditions precedent relating to, for example, the carriage of an Inventory or Hazardous Materials ('green passport') and to selling the ship to a responsible party for dismantling. Depending on the language of the loan agreement, breaches of these provisions may trigger an event of default, or in any case, provide the lender with a legal basis to engage with their client.

\section{- Green Loan Principles}

After green bonds becoming an increasingly common financing instrument, a growing demand for green loans has now emerged. In March 2018, the Loan Market Association (LMA) ${ }^{25}$ and the Asian Pacific Loan Market Association published the Green Loan Principles (GLP). ${ }^{26}$ The GLP provide a framework for determining whether a loan may be labelled as 'green'. A green loan is

${ }^{20}$ Covenants are continuing obligations of the borrower to do or not do certain things. EP covenants usually require compliance with environmental and social management plans and actions plans and periodic reports relating to these plans.

21 The so-called category $A$ and $B$ projects

22 EP Guidance for EPFIs on incorporating environmental and social considerations into loan documentation, $\mathrm{p}$. 1 and 2.

23 'Conditions precedent' require the borrower to fulfil certain environmental or social related conditions before (part of) the loan is drawn and through 'representations and warranties', the borrower (repeatedly) confirms designated facts and circumstances relating to human rights and the environment.

${ }^{24}$ https://www.nibc.com/media/1571/responsible-ship-recycling-statement.pdf

25 The European trade association for banks and other financial actors active on the international loan markets

${ }^{26}$ Recently updated (11 December 2018) to include input from US industry body the Loan Syndications and Trading Association (LSTA) 
exclusively used to (re)finance eligible 'green projects': projects with clear environmental benefits. ${ }^{27}$ The proceeds of the green loan, or of a tranche of the loan, ${ }^{28}$ are utilised only for this specific green project. Unlike the EPs and the RSRS, the GLP do not provide guidance on contractual provisions. However, they do outline the four components of a green loan: use of proceeds, green project selection and evaluation, management of proceeds and reporting. Considering that utilisation of the loan proceeds is one of the fundamental determinants of a green loan, this must be appropriately described in the use of proceeds clause. The other components, in particular the reporting component, are likely to be reflected in the loan terms by way of covenants, conditions precedent or representations and warranties.

\subsection{Current practice of contractual provisions in general corporate lending}

The frameworks discussed above are deployed in project or asset based finance. These types of loans are aimed at developing or purchasing a specific project or asset. The purpose clause in these loans usually reflects that the loan proceeds may only be used to cover construction or purchasing costs of the relevant project or asset. General corporate loans are divergent. These loans do not relate to a specific project or asset, but are aimed at financing businesses' more general expenses, such as working capital or refinancing existing debt. The purpose provisions in these loans are typically broad, enabling borrowers to use the loan for all intended purposes. Therefore, it is often difficult for lenders to track how the funds are being used by the borrower. If banks cannot ascertain how loan proceeds are being used, they cannot rule out that proceeds are linked to human rights impacts. Hence, the traditional corporate lending structures seem to pose a barrier for banks to conduct human rights due diligence in line with the UNGPs and OECD Guidelines. However, the rise of so called 'sustainability linked loans' for corporate clients may change this, as we will further discuss in section 5.

\section{Why banks are hesitant to include human rights provisions in loan documentation}

\subsection{Human rights performance is hard to measure}

The term ESG (Environmental, Social and Governance) is commonly used in the financial world. Considering the ' $E$ ', climate change has become a priority on the financial sector's agenda in the recent years due to the 2015 Paris Agreement and the subsequent plans to 'green' the financial system. ${ }^{29}$ Considering the ' $\mathrm{G}$ ', banks are quite familiar with this criterion due to $\mathrm{EU}$ and national 'Know Your Customer' (KYC) compliance produces on money laundering, corruption and terrorism activities. Considering the ' $\mathrm{S}$ ' of social, approaches of banks are less well developed. We have found an increased awareness of banks that their products and services have an impact on society and that approaches to deal with this need to be implemented in policies and procedures. The reason why the ' $S$ ' is less well developed may be found in the inability to measure and track client performance on human rights. Regarding the environment, banks are increasingly using climate related metrics - such as greenhouse gas emissions - to measure

\footnotetext{
27 According to the "Green Loan Principles" (GLP) as published by the Loan Market Association and the Asian Pacific Loan Market Association in March 2018 https://www.Ima.eu.com/application/files/9115/4452/5458/741_LM_Green_Loan_Principles_Booklet_V8.pdf

28 The GLP provide that a green loan may take the form of one or more tranches of a loan facility.

${ }^{29}$ E.g. the EC Action plan Financing Sustainable Growth, the EU Sustainable Finance taxonomy and the Dutch banks' commitment to the Dutch climate agreement.
} 
environmental performance of clients. To date, reliable metrics, targets or performance indicators to measure and track client performance on human rights are lacking. Greenhouse gas emissions are quantifiable, but human rights are generally not. Quantifying human rights requires social circumstances to be translated into quantitative and comparable metrics. To enable this, banks need access to adequate, comparable and suitable data. However, metrics in this respect are not easy to develop: the impact of human rights violations may be experienced differently by those affected, the group of affected stakeholders may not be easy to identify and the effects of human rights violations, for example one gross violation vis-à-vis many smaller ones, may not be easy to compare with one another. Meaningful engagement with affected stakeholders and well-designed (operational) grievance mechanisms at the client level could be helpful to acquire data and develop metrics. However, as long as banks cannot ascertain how and where - general corporate loan proceeds are being used, local engagement and grievance mechanisms remain a challenge.

Furthermore, a 2017 NYU Stern study concluded that too often, social performance is measured by looking at the efforts of companies instead of at the effects of those efforts. While from a long term perspective it is better to measure the effects of company efforts, measurement generally focuses on information that companies have ready access to and are willing to disclose, such as human rights policies and procedures. ${ }^{30}$

\subsection{Principle based language is not suitable for loan documentation}

Contractual terms in commercial contracts, such as loan documents, are formulated as precisely as possible to avoid ambiguity, litigation and cost. Therefore, loan provisions require sufficiently specific language. Language derived from the UNGPs and OECD Guidelines is often ambiguous or too broad and therefore not suitable for integration in loan documentation. Loan documentation for (syndicated) facilities is largely standardised by the LMA. The LMA has developed standard loan documentation with boilerplate provisions to facilitate efficient negotiation between lenders and borrowers. Although not mandatory, it is the recommended form for syndicated facility agreements and has become the market standard on the global loan market. For human rights related provisions to develop into market practice, a conversion of principal based language into suitable LMA lending language is required.

\subsection{Lack of international consensus and urgency}

LMA templates are regularly amended to keep pace with legal and regulatory developments. However, the LMA requires a certain level of consensus among users for the inclusion of provisions in recommended form documentation. ${ }^{31}$ An example is the consensual integration of FATCA provisions into LMA templates, as a result of extraterritorial US tax evasion laws. Such level of consensus is still to be achieved in the areas of anti-corruption and sanctions, both also heavily regulated through extraterritorial (mostly US and UK) legislation applicable to banks. Hence, the LMA considered the implementation of standard sanctions and anti-corruption provisions not to be appropriate yet. However, it did develop guidance notes and the LMA

30 "Putting the "S" in ESG: Measuring Human Rights Performance for Investors", p. 16, 18 - 19, 25 NYU Stern Center for Business and Human Rights, March 2017.

31 Slaugther and May, The ACT Borrower's Guide to LMA Loan Documetnation for Investment Grade Borrowers, 2017, P.9 
documents include footnotes to consider these topics. ${ }^{32}$ As a result, more and more contractual assurances in the areas of anti-corruption and sanctions are nowadays included in loan documentation. Similarly, LMA guidance notes, riders and footnotes could be developed in the area of human rights. That said, international consensus is less well developed here in connection with loan documentation compared to anti-corruption and sanctions. Noncompliance of the abovementioned FATCA legislation may lead to heavy penalties and reputational risks for banks. It is common knowledge that where legal and commercial risks of non-compliance are high, express provisions are more likely to be included in contracts. ${ }^{33}$ Banks currently do not face the same threat of statutory sanctions when not complying with human rights norms. The UNGPs and OECD Guidelines are voluntary and lack enforcement action and (extraterritorial) national legislation is still scarce. Hence, there is currently no urgency on the international loan market to integrate human rights provisions into standard documentation. However, as national (extraterritorial) legislation (for example the EU Regulation on conflict minerals and the Dutch law on child labour) is emerging this may be a temporary challenge.

\subsection{Leverage poses a challenge in syndicates}

On the global loan market banks operate internationally and often in syndicates. In a syndicated Ioan facility, multiple banks work together providing a borrower the capital needed. The 'lead bank $^{\prime 34}$ is responsible for all aspects of the deal, including negotiating terms, putting together the syndicate, reporting and monitoring. Since the lead bank is negotiating the (broad) terms with the borrower in a very early stage, there might be considerable leverage to include assurances in relation to human rights in the opening proposal to the borrower. ${ }^{35}$ This may direct and shape the further negotiating process of the loan. Being a syndicate member, typically less leverage exists to negotiate contractual assurances on human rights. Terms are often negotiated before syndicate partners are approached and banks need to rely on the willingness of the lead bank as the liaison with the borrower. Banks seem to have most influence on the terms of the loans when acting as a lead bank in a syndicate or when providing a non-syndicate, bilateral loan. In both syndicated and bilateral loans, sustainable committed banks are often getting push back from borrowers on proposed human rights assurances, arguing that they are the only bank seeking such assurances. In a borrower friendly market, borrowers may consider another bank willing to provide the loan without these assurances. Establishing alliances and developing principles with other sustainability committed international (EP) banks, when participating in syndicates, might be an avenue to consider. Obviously, banks should observe the limits imposed by competition law and banks should actively seek legal advice when establishing these alliances. The RSRS could be used as an example of a successful (sector) alliance where banks jointly raise the bar on human rights. This may eventually also lead to more - joint - leverage of syndicate members.

\footnotetext{
32 Slaughter and May, The ACT Borrower's Guide to LMA Loan Documentation for Investment Grade Borrowers, 2017, P.9

33 Katerina P. Mitkidis, Sustainability Clauses in International Supply Chain Contracts: Regulations, Enforceability and Effects of Ethical Requirements, Nordic Journal of Commercial Law, Issue 2014 \#1, p. 159

${ }^{34} \mathrm{~A}$ wide variety of terms is used depending on the characteristics of the loan, stage of the loan and tasks of the lead bank: e.g. "agent", "arranger", "mandated lead arranger", "loan coordinator".

35 This has become market practice for the topic of "sanctions".
} 


\section{The potential of sustainability linked loans in the area of human rights}

\subsection{The rise of sustainability linked loans}

Banks are increasingly using 'sustainability linked loans' in their corporate lending activities. To promote the development and preserve the integrity of the sustainably linked loan product, the Sustainability Linked Loan Principles (SLLP) were published in March 2019. ${ }^{36}$ According to the SLLP, a sustainability linked loan is a loan incentivising a borrower's achievement of ambitious, predetermined sustainability performance objectives. While green loans have become an increasingly common financing instrument, sustainability linked loans have a higher potential in terms of human rights. To start with, and as opposed to green loans, sustainability linked loans have an overall ESG focus allowing for social (and governance) targets to be included in the loan conditions. Beyond this, the use of proceeds in sustainability linked loans is not restricted to specific projects. The loan proceeds can be broadly used for financing expenses of the company, making sustainability linked loans a useful instrument for making the clients business more sustainable. The key characteristic of a sustainability linked loan is that a borrower's sustainability performance is measured against predetermined sustainability performance targets (SPTs). It aims to improve a borrower's sustainability profile by aligning loan terms to the borrowers performance against the SPTs. ${ }^{37}$ Typically, the interest clause is aligned to the borrowers' sustainability performance. This is done by agreeing on a variable interest clause, whereby the interest on the loan decreases if the borrower meets its SPTs and increases when the borrower does not meet its SPTs. The perspective of a reduced interest rate incentives the borrower to meet its sustainability targets.

Appendix 1 to the SLLP lists common categories of SPTs that banks could use in sustainability linked loans. However, the majority of suggested SPTs focus on a borrower's environmental performance. The only 'social' SPT on the list relates to affordable housing: the number of affordable housing units a borrower develops. Hence, when banks want to incentivize a borrowers human rights performance through as sustainability linked loan, banks need to develop human rights focused SPTs.

\subsection{Human rights focused sustainability performance targets}

The foregoing begs the question which appropriate human rights focused SPTs banks may use in a sustainability linked loan. Before we dive into this, it is important to distinguish two types of SPTs currently used: (1) SPTs based on the borrower's overall ESG ratings provided by external benchmarks or rating agencies and (2) SPTs based on specific sustainability performance indicators or targets, tailored to the business of the borrower. When the sustainability linked loans were introduced in 2017, we typically saw the first type of SPTs. ${ }^{38}$ Now sustainability linked

36 "Sustainability Linked Loan Principles" as published by the Loan Market Association, the Asian Pacific Loan Market Association and the Loan Sydicated and Trading Association in March 2019, https://www.Ima.eu.com/application/files/8015/5307/4231/LMA_Sustainability_Linked_Loan_Principles.pdf

37 https://www.Ima.eu.com/application/files/8015/5307/4231/LMA_Sustainability_Linked_Loan_Principles.pdf, p. 3.

38 Philips facility: https://www.ing.com/Newsroom/All-news/ING-and-Philips-collaborate-on-sustainableloan.htm Olam facility: https://www.olamgroup.com/news/all-news/press-release/olam-internationalsecures-asias-first-sustainability-linked-club-loan-facility-us500-0-million.html 
loans with specific SPTs are deployed too. ${ }^{39}$ Specific SPTs allow the lender to target its leverage towards ESG topics which are particularly relevant to a specific borrower. In terms of human rights, it makes sense to develop SPTs that are linked to the borrower's so called salient issues: those human rights that are at risk of the most severe negative impact through the company's activities or business relationships. ${ }^{40}$ With a few exceptions, ${ }^{41}$ most rating agencies and corporate benchmarks do not apply this "impact to people" lens. In relation to companies that publicly report on their salient issues, banks are encouraged to discuss with these clients how corresponding SPTs can be developed for the loan facility.

As mentioned before, these SPTs preferably measure the effects of company efforts instead of the company efforts itself. This means that SPTs on number of reported human rights violations, number of complaints and grievances, number of jobs created, diversity among senior leadership, numbers of accidents in the working place are considered more valuable than SPTs on client's policies, procedures, audits, risk assessments, internal trainings and stakeholder consultation etc. ${ }^{42}$ Hence, banks should strive to include 'effect based SPTs' into their sustainability linked loan documentation, linked to the company's salient issues (if any). Where this is not feasible, realistic or necessary (e.g. with low risk clients) 'effort based SPTs' may suffice. Banks are increasingly using human rights SPTs in their corporate loans. We have recently seen loans whereby effect based SPTs were included in turn for a lower interest rate: a social housing association that is required to assist 600 of its residents to work, a waste company that is required to reduce its workplace accident rate, a social housing association that is required to deliver an agreed number of childcare qualifications and a metallurgic company that is required to safely store its mine waste. ${ }^{43}$ The latter loan referred to also contains an interesting effort based SPT whereby the metallurgic company is required to support and engage with local communities.

Once human rights SPTs are negotiated with the client, loan conditions can be aligned with them. In terms of aligning loan terms, banks are encouraged to move beyond the interest clause. The SLLP provides leeway to align all terms of the loan to sustainability targets. ${ }^{44}$ Therefore, the agreed SPTs may be reflected in other parts of the loan documentation. For instance, banks may explore how achieved SPTs could entitle the borrower to increased facility amounts, an earlier drawdown, fee reduction, less strict mandatory prepayment obligations and, in case of term

${ }^{39}$ Cocobod facility: https://www.globalcapital.com/article/b1dm9xkm994q5q/cocobod-plants-esg-loans-in-embut-not-all-taste-the-sweetness, Renewi facility: https://www.renewi.com/-/media/pdf/news-releasesarchive/2018/pr-17-05-2018.pdf?la=en, COFCO facility: https://www.ing.com/Newsroom/All-news/INGstructures-and-coordinates-largest-ever-sustainability-improvement-loan-in-commodity-trading.htm,

40 https://www.ungpreporting.org/wp-content/uploads/UNGPReportingFramework_withguidance2017.pdf, p. 22

41 For example: https://www.corporatebenchmark.org/

42 "Putting the "S" in ESG: Measuring Human Rights Performance for Investors", p. 18 - 19, NYU Stern Center for Business and Human Rights, March 2017.

43 L\&Q facility, https://www. theguardian.com/society/2019/aug/11/lq-and-bnp-paribas-partner-up-to-gettenants-back-into-work, Renewi facility, https://www.renewi.com//media/renewi/investors/documents/green-finance-framework-rns.pdf?la=en, Peabody facility: http://www.bnpparibas.co.uk/en/2019/08/14/peabody-and-bnp-paribas-partner-to-boost-social-impact/ and Polymetal facility, https://www.rosbank.ru/en/company-profile/presscenter/societe-generale-hasagreed-a-bilateral-sustainability-linked-credit-facility-with-polymetal/

44 "...look to improve the borrower's sustainability profile by aligning loan terms to..." https://www.Ima.eu.com/application/files/8015/5307/4231/LMA_Sustainability_Linked_Loan_Principles.pdf, p. 3. 
loans, reduced commitment fees on and the ability to re-draw loan amounts. These benefits may provide additional incentives for borrowers to accept these SPTs.

\section{A global standard on human rights provisions in corporate lending}

\subsection{Importance of a level playing field: recommendations}

It is in the interest of human rights committed and internationally operating banks that a level playing field on human rights is created on the international corporate lending market. After all, if these banks raise the bar internationally but other (commercial) banks do not follow suit, they may no longer be able to compete on the international loan market if they stick to these human rights requirements. But most importantly, an international level playing field is in the interest of those (potentially) impacted by human rights impacts on the ground. If human rights provisions become the market standard, this may lead more human rights compliance by companies on the ground.

In section 4 we have given four reasons why banks are hesitant to include human rights provisions in corporate loans: (i) human rights performance is hard to measure, (ii) principle based language is not suitable for loan documentation, (iii) international consensus and urgency lacks and (iv) insufficient leverage in syndicates. If we rephrase these challenges in opportunities, the following recommendations can be made for banks and industry trade bodies:

I. Develop human rights focused SPTs that measure effects of clients human rights performance in connection with the salient human rights risks.

II. Convene business and human rights experts and banking and finance lawyers to turn principle based language into suitable corporate lending language.

III. Incentivize standard setting trade associations (such as LMA) to develop suitable guidance notes, riders and footnotes on human rights.

IV.

(a) Where banks are lead bank in a syndicate or when they provide bilateral loans, use leverage in early stage to negotiate contractual human rights assurances.

(b) Where banks are part of a syndicate, form alliances with other sustainability committed international banks to create joint leverage.

\section{Practical guidance for human rights provisions}

To facilitate the follow up of recommendation I, II and III, we provide banks (and their legal advisors) with practical guidance for negotiating possible human rights provisions in loan agreements. The suggestions are based on (i) the EP and RSRS guidance on incorporating contractual language and (ii) the language and structure of the LMA Investment Grade 
Agreement. ${ }^{45}$ In this guidance, we use the term "Company" for the borrower and "Lender" for the bank. Depending on the loan documentation, other terms can be used, e.g. "Obligor" or "Borrower" for the borrower or "Finance Parties" or "Bank" for the lender(s).

\section{Definitions}

This clause sets out the definition of key terms that are used in the loan agreement. When including the human rights related provisions suggested below, the following definitions need to be brought in line:

\section{a. [Margin]}

Suggestion: The margin component can be made variable by linking it to the borrowers social performance by including effect based SPTs: ${ }^{46}$

\section{Guidance:}

"Margin" means [...] per cent. per annum, but if (to the satisfaction of the Lenders) the following targets have been met [to include effect based SPTs, such as:],

- Reduction of [...\%] of number of human rights related complaints and grievances related to [defined salient human rights issue];47

- Reduction of [...\%] of reported child labour within the Company, its Subsidiaries or its supply chains (which extends to the production of goods acquired through this supply chain) shown by consecutive audits by an independent third party and/or through certification;

- Reduction of [...\%] of reported forced labour within the Company, its Subsidiaries or its supply chains (which extends to the production of goods acquired through this supply chain) shown by consecutive audits by an independent third party and/or through certification;

- Number of jobs created by the Company;

- Provision of child care for (female) workers in the proximity of the workplace;

- Diversity ratio male -female 50-50 in upper management and/or employee's representative body;

- Reduction of [...\%] of number of (fatal and non-fatal) accidents in the working place;

- The establishment of an employee's representative body;

- The existence of a collective bargaining agreement;

- The establishment of lockers in which (migrant) workers may keep their passports;

- $\quad . .48$

45 The Investment Grade Agreements are the most widely used LMA template documents and the 'plain vanilla' of the LMA's various forms of facility agreement. See Slaughter and May, "The ACT Borrower's Guide to the LMA's Investment Grade Agreements", September 2017.

${ }^{46}$ As referred to above, avoid SPTs that only measure the company's efforts, such as policies, procedures, audits, risk assessments, internal trainings and stakeholder consultation. Instead, include SPTs measuring the effects of company efforts.

47 Provided the Company has an in- or external complaint mechanism in place which allows complaints from individuals or entities external to the Company or its Subsidiaries and is [UNGP 31 compliant and] assessed and approved by the Lender.

48 To be tailored to the salient risks of the borrower. 
then Margin will be reduced to [...] per cent. per annum. The difference between the Margin and the reduced Margin will be deposited into [a human rights related fund/project].

b. [Material Adverse Effect]

Suggestion: When there are human rights related concerns, lenders could consider including human rights compliance by the Company.

Guidance (additions underlined):

"Material Adverse Effect" means [in the reasonable opinion of the Majority Lenders/ the Sustainability Agent] a material adverse effect on:

a) [the business, operations, property, condition (financial or otherwise), or prospects of the Group taken as a whole; or

b) the compliance of the Company with human rights law and standards;

c) $\ldots$

\section{Purpose}

This provision specifies the purpose to which each of the facilities may be applied. When a lender is aware of human rights risk associated with certain activities of the borrower (or a subsidiary) it may want to avoid that facilities are used for those activities.

Suggestion: Lenders may consider to specify the activities to which the loan may not be applied by the company.

Guidance:

The Company shall not apply amounts borrowed by it under the Facility towards [ ].

\section{Conditions of Utilisation}

This clause provides that the borrower must provide all items precedent listed in the conditions precedent schedule to the loan agreement. Conditions precedent ("CPs") are pre-conditions that must be satisfied before the funds are made available to the borrower. Hence, CPs are an important leverage tool and can be used to require the borrower to make progress on social issues.

Suggestion: Include CPs based on human rights risks associated with the operations of the borrower.

Guidance:

- [Human Rights policy]

- A copy of the human rights policy of the Company showing how it assesses, responds to and remedies human rights issues within the Company as well as its supply chains which extend to the production of the goods acquired through the supply chain as well as the way in which it has established a continuous learning mechanism to decrease the number of previously mentioned human rights issues.

- A description of its operations and/or a copy of a map of its supply chain(s) in which the Company has identified its salient human rights risks.

- [Land rights and indigenous peoples]

- Copies of all approvals or permits required for the operations of the Company under applicable host-country laws [countries $X, Y, Z$ ] and regulations relating to environmental protections, social protection and human rights (including land 
rights), as well as proof of Free Prior and Informed Consent if the Company has [have] acquired land rights for its [their] operations.

- [Trade union rights / collective bargaining]

- A certificate of the Company (signed by a director) confirming that it has established and maintains an employee's representative body, such as an employee organisation or trade union.

- A copy of all collective bargaining agreements in place between the Company and the employee's representative body, duly signed by the chair of the employee representative body.

- [Diversity]

- A certificate of the Company (signed by a director) reflecting the male-to-female ratio among the employees of the Company and among the management of the Company, countersigned by the chair of the employee's representative body.

- [Responsible dismantling/decommissioning of particular assets]

- A certificate of the Company (signed by a director) listing all the potentially hazardous materials present in [a particular asset] of the Company.

- [Complaints and grievances]

- A certificate of the Company (signed by a director) confirming that it has established or participates in an in- or external operational-level grievance mechanism which allows for complaints of individuals, entities and communities that may be impacted by the operations of the Company.

- Evidence that the Company has actively and adequately communicated (e.g. through internal channels, following audits or through local newspapers) the existence of the operational-level grievance mechanism to all relevant in-and external stakeholders.

- [Health and Safety]

- A certificate of the Company (signed by a director) listing the fatal and non-fatal accidents on the workplace of the Company, countersigned by the chair of the employee representative body. If audits by independent parties have taken place on Health and Safety, a copy of the latest audit report.

- [Forced labour]

- Evidence that employees of the Company have free access to a personal locker to safe keep personal documents, such as passports.

- If audits by independent parties have taken place on forced labour, a copy of the latest audit report.

- [Stakeholder consultation]

- A policy on stakeholder engagement of the Company in connection with its salient human rights risks including the following elements: stakeholder analysis and planning, disclosure and dissemination of information, consultation and 
participation, grievance mechanism, and ongoing reporting to affected

communities. ${ }^{49}$

- [Information on supply chains]

- A confirmation by the Company that a contractual mechanism or procurement strategy is in place to oblige suppliers to comply with human rights requirements and to provide information on human rights compliance in the supply chain, e.g. through a supplier code of conduct, regarding (self-assessment) questionnaires, obligatory training of suppliers or aggregated information on number, nature and origin of complaints in the grievance mechanisms of these suppliers.

- [Human rights reporting]

$\bigcirc$ A copy of the integrated or standalone human rights report in accordance with the UNGP Reporting Framework.

- A legal opinion of [...], confirming the validity of the documents listed above.

\section{Fees}

Suggestion: Use fee-arrangements in the loan documentation to incentivise respect for human rights by borrowers. As with the interest margin, human rights SPTs (tailored to the borrowers salient human rights issues) could be included to lower the commitment fee, arrangement fee, agency fee or any other fee.

Guidance:

- $\quad$ The accrued [commitment] fee shall be reduced with a percentage of [...] per cent. per annum if (to the satisfaction of the Lenders) the following targets are met [to include effect based SPTs, such as:]:

- Reduction of [...\%] of number of human rights related complaints and grievances related to [defined salient human rights issue]; ${ }^{50}$

- Reduction of [...\%] of reported child labour within the Company, its Subsidiaries or its supply chains (which extends to the production of goods acquired through this supply chain) shown by consecutive audits by an independent third party and/or through certification;

- Reduction of [...\%] of reported forced labour within the Company, its Subsidiaries or its supply chains (which extends to the production of goods acquired through this supply chain) shown by consecutive audits by an independent third party and/or through certification;

- Number of jobs created by the Company;

- Provision of child care for (female) workers in the proximity of the workplace;

- Diversity ratio male -female 50-50 in upper management and/or employee's representative body;

- Reduction of [...\%] of number of (fatal and non-fatal) accidents in the working place;

49 Based on PS 1 of the IFC Performance Standards on Environmental and Social Sustainability.

50 Provided the Company has an in- or external complaint mechanism in place which allows complaints from individuals or entities external to the Company or its Subsidiaries and is [UNGP 31 compliant and] assessed and approved by the Lender. 
- The establishment of an employee's representative body;

- The existence of a collective bargaining agreement;

- The establishment of lockers in which (migrant) workers may keep their passports;

- $\quad .{ }^{51}$

\section{Representations}

Representations are statements by the borrower of facts and circumstances on the basis of which the lender enters into the agreement. When there are concerns about human rights, lenders could seek contractual assurances on these topics in the form of specific representations and designate these as repeating representations.

a. [Complaints and grievances]

Suggestion: Extend the "No proceedings" representation to cover human rights related complaints and grievances filed with any complaints or grievance mechanism and OECD national contact points.

\section{Guidance (additions underlined):}

- No litigation, arbitration, administrative proceedings, or human rights related claim, notification, complaint or grievance of or before any court, arbitral body, agency, OECD National Contact Point, complaints mechanism or grievance mechanism, which, [if adversely determined, might reasonably be expected to have a Material Adverse Effect ${ }^{52}$ has or have (to the best of its knowledge and belief) been started or threatened against it or any of its Subsidiaries.

- No judgment, order or statement of a court, arbitral body, agency, OECD National Contact Point, complaints mechanism or grievance mechanism, [which might reasonably be expected to have a Material Adverse Effect] ${ }^{53}$ has (to the best of its knowledge and belief) been made against it or any of its Subsidiaries.

b. [Compliance with human rights laws and standards]

Suggestion: Include a specific representation confirming the compliance of the borrower with human rights law and standards

\section{Guidance:}

It at all times complied, currently complies and will continue to comply with (i) hostcountry government laws, rules, regulations, orders, relating to the protection of human rights, (ii) international standards on human rights such as [e.g. the International Bill of Human Rights, the UNGPS, OECD GL, specific ILO conventions] and (iii) industry standards on human rights [e.g. the Initiative for Responsible Mining Assurance, Roundtable on Sustainable Palm Oil].

c. [Appointment of social consultant]

Suggestion: appoint a social consultant for the Company.

\section{Guidance:}

\footnotetext{
51 To be tailored to the salient risks of the borrower.

52 To be removed if compliance with human rights law and standards is not included in the definition of Material Adverse Effect.

53 To be removed if compliance with human rights law and standards is not included in the definition of Material Adverse Effect.
} 
The Company has appointed an independent social consultant, in accordance with agreed terms and acceptable to the Lenders, who will provide to the Lenders relevant reports on the human rights risks and impacts associated with the Company.

We would like to conclude this part with three more general suggestions for human rights related representations:

d. [Repeating representations]

Suggestion: Lenders could consider to designate human rights related representations as repeating representation, as has become market practice for sanctions and anti-corruption representations. This should be reflected in the definition of "Repeating Representations".

e. [No qualification to knowledge]

Suggestion: Some representations are qualified by reference to the knowledge of the borrower. This means that the borrowers confirms facts or circumstances that it is actually aware of, not those that the borrower should have been aware of. Lenders could consider not to qualify human rights related representations to the borrowers knowledge by avoiding the words "so far as aware" and "to the best of its knowledge".

f. [Subsidiaries]

Suggestion: If human rights are not so much a concern at the level of the borrower but rather on the level of its subsidiaries, lenders should ensure that (repeating) representations are given by both the borrower and its subsidiaries. The LMA standard documentation already provides this by using the term "Each Obligor".

\section{Undertakings}

Through undertakings or covenants, the borrower promises to undertake certain actions or to refrain from taking certain actions. A loan agreement typically consists of three types of undertakings: information undertakings, financial undertakings and general undertakings.

a. [Information undertakings - miscellaneous information]

Suggestion: Lenders could consider including human rights related information in the miscellaneous information clause.

Guidance (additions underlined):

The Company shall supply to the Lender:

a) Every [...] months a report with aqgreqate information regarding the number and nature of complaints or grievances received by any operational-level grievance mechanism of any member of the Group regarding [defined salient human rights issue].

b) promptly upon becoming aware of them, the details of any litigation, arbitration, administrative proceedings or a complaint with a OECD National Contact Point which are current, threatened or pending against any member of the Group [, and which might, if adversely determined, have a Material Adverse Effect ${ }^{54}$;

c) promptly upon becoming aware of them, the details of any judgment, order or statement of a court, arbitral body, agency, OECD National Contact Point, which

\footnotetext{
54 To be removed if compliance with human rights law and standards is not included in the definition of Material
} Adverse Effect. 
is made against any member of the Group [, and which might have a Material Adverse Effect $]^{55}$;

d) promptly upon becoming aware of them, the details of any event resulting in:

a. [Health \& Safety] death or multiple injury of an employee of the Company;

b. ...56

e) promptly, such further information regarding the financial condition, business and operations (including information on human rights issues within its operations) of any member of the Group as any Finance Party (through the Agent) may reasonably request.

b. [Information undertakings - Reports on social performance]

Suggestion: In addition to the miscellaneous information clause, lenders could consider including a clause on human rights related reporting.

Guidance:

The Company shall supply to the Lender:

a) an annual report, prepared by an independent third party expert on business and human rights, documenting compliance with [the SPTs defined in the loan agreement, e.g. in Margin definition or Commitment Fee)];

b) an annual report, prepared by an independent third party expert on business and human rights, documenting compliance with (i) host-country government laws, rules, regulations, orders, relating to the protection of human rights, (ii) international standards on human rights such as [e.g. the International Bill of Human Rights, the UNGPS, OECD GL, specific ILO conventions] and (iii) industry standards on human rights [e.g. the Initiative for Responsible Mining Assurance, Roundtable on Sustainable Palm Oil];

c) an annual report, prepared by an independent third party expert on business and human rights, documenting how the Company has conducted stakeholder consultation over the previous year; and

d) a bi-annual integrated or standalone human rights report in accordance with the UNGP Reporting Framework.

c. [General Undertakings - Compliance with laws]

Suggestion: The standard clause requires the borrower to comply with laws, but only to the extent necessary for performing its obligations under the loan agreement. When human rights are a concern, lenders could consider extending this undertaking by including compliance with human rights laws and/or standards.

Guidance (additions underlined):

The Company shall comply in all respects with all laws to which it may be subject, if failure so to comply would materially impair its ability to perform its obligations under the Finance Document or would lead to non-compliance of such Company with (i) hostcountry government laws, rules, regulations, orders, relating to the protection of human rights, (ii) international standards on human rights such as [e.g. the International Bill of Human Rights, the UNGPs, OECD GL, specific ILO conventions] and (iii) industry standards

\footnotetext{
55 To be removed if compliance with human rights law and standards is not included in the definition of Material Adverse Effect.

${ }^{56}$ To be tailored to the salient risks of the borrower.
} 
on human rights [e.g. the Initiative for Responsible Mining Assurance, Roundtable on Sustainable Palm Oil].

\section{d. [General Undertakings - Compliance with human rights laws applicable to the Lender].}

Suggestion: In the area of sanctions, it is current market practice to include undertakings on the borrower's compliance with sanction rules and the use of proceeds in breach of relevant sanctions. If human rights laws are relevant to lenders and could lead to similar legal and reputational risk for the lenders, they could consider including a specific undertaking.

\section{Guidance:}

The Company shall comply in all respects with human rights laws to which the Lenders may be subject and will not use not use loan proceeds for any purpose which would breach human rights related legislation applicable to the Lender.

\section{e. [General Undertakings - Stakeholder engagement].}

Suggestion: Meaningful engagement of the borrower with its stakeholders can be an effective tool to prevent and mitigate legal and financial risks. Lenders could consider including an undertaking on stakeholder consultation.

\section{Guidance:}

The Company shall conduct ongoing stakeholder engagement regarding its salient human rights risks which includes the following elements: stakeholder analysis and planning, disclosure and dissemination of information, consultation and participation, grievance mechanism, and ongoing reporting to affected communities. ${ }^{57}$

\section{Events of Default}

This clause lists the events that qualify as Events of Defaults: i.e. events that trigger the right of the lender to demand immediate repayment of the loan. When human rights related definitions, conditions precedent, representations and undertakings are included in the loan documentation, these Event of Default provisions do not require human rights related language themselves. That said, we encourage lenders (i) not to allow for a grace period longer than the standard 15-30 days for breaches of human rights related CPs, representations or undertakings and (ii) not to soften breaches of human rights related representations by including materiality qualifications. This will avoid a discussion with the borrower on whether a breach of human rights representation is incorrect or misleading 'in any material respect' and (iii) on a more general note, to consider whether an exit due to a breach of human rights related provisions sufficiently addresses the human rights issue at hand. Continuing to be a lender enables banks to exercise leverage and create positive incentives. This could eventually be more effective than an exit strategy.

In the sanction space, some lenders consider a mandatory prepayment right a more appropriate consequence than accelerating on an Event of Default. A mandatory prepayment right triggers the cancellation of commitments and the requirement of the mandatory prepayment of outstanding loans upon a certain event, usually a change of control. The clause could be drafted in such a way that lenders can choose to exit on an individual basis. Lenders could explore

57 Based on PS 1 of the IFC Performance Standards on Environmental and Social Sustainability. 
whether an individual mandatory prepayment right could be triggered by a human rights related breach. Upon such breach, lenders could make the individual choice to cancel their commitments without having to depend on the syndicate.

\section{Confidential information}

This section contains undertakings from the lender to keep 'Confidential Information' confidential. The term Confidential Information is broadly defined and covers all information relating to the borrower, its subsidiaries, the group and the loan documentation. Hence, lenders are restricted to talk about the borrower and disclose the client relationship. This could pose a problem when the borrower is associated with human rights impacts and the lender would like to react in public or seek assistance from third parties. HSBC bank recognized this as a frustration and amended its agricultural commodities policy to be able to disclose the client relationship with palm oil clients. New clients in palm oil are now required to consent to HSBC being able disclose publicly whether the customer is or was a customer. ${ }^{58}$ Due to the restrictions to (i) new clients and (ii) palm oil, it is unclear what the effect of this policy is going to be. However, it is a valuable first move and serves as an example to other banks. The possibility of disclosing the client relationship through obtaining client consent is currently in the LMA standard documentation and does not require amendment.

\section{a. [Confidentiality \& Disclosure of Confidential Information]}

Suggestion: In addition, banks are encouraged to include or alter the following permitted disclosures in clause 36.2 (b).

Guidance (additions underlined):

- (vi) to whom information is required to be disclosed in connection with, and for the purposes of, any litigation, arbitration, mediation, administrative, human rights related complaints or grievance procedures regarding [defined salient human rights issuel or other investigations, proceedings or disputes;

- $(x)$ the existence of the client relationship with the Company, in the event that the Company is under great public scrutiny in relation to environmental and/or human rights issues.

- (xi) aggregated information on lending portfolio level [within specific sectors] on sustainability performance based on information received from the Company.

\section{Other considerations}

In the beginning of this article we discussed that the legal landscape relating to business and human rights is slowly transitioning from international non-legally binding frameworks into legally binding national legislation. Two standard clauses in loan agreements could become relevant in this respect, depending on the content of the legislation:

a. [IIlegality]. This clause provides that if it becomes unlawful for a lender to perform its obligations under the loan agreement, the lender may exit the loan by requiring the borrower to prepay on request. If (future) legislation on human rights due diligence is adopted which renders it illegal to lend funds to that particular borrower, the lender may rely on the current LMA template wording of the Illegality-clause.

b. [Know Your Customer checks]. This clause provides requires the borrower to provide information to the lenders for the purpose of satisfying 'know your customer/KYC'

\footnotetext{
58 https://www.hsbc.com/-/files/hsbc/media/media-release/2017/170220-hsbc-agricultural-commoditiespolicy.pdf, p.3
} 
requirements. Although originally drafted for anti-money laundering laws and regulations, the current broad wording ("..."know your customer" or similar identification procedures") would allow future human rights due diligence requirements imposed to lenders, to be included.

\section{Conclusion}

In this article we have elaborated how banks could take up their responsibility to respect human rights by including provisions on human rights into loan documentation. We have seen that banks do care about human rights but may be reluctant to include human rights related provisions in (general corporate) loan agreements. We have discussed which hurdles have to be overcome in order to include meaningful human rights provisions in loan documentation and we have discussed how sustainability linked loans can be used to address human rights issues in general corporate lending. We have furthermore, taking LMA standard loan documentation as a starting point, elaborated several additions and alterations, which can be made to loan documentation in order to strengthen respect for human rights by borrowers.

We are conscious of the fact that it may not be feasible in practice to implement all suggestions for improvement at once. Borrowers may be hesitant to accept highly elaborated paragraphs on human rights compliance, especially if other lenders do not impose similar requirements. Current standard market lending practices may hamper the adoption of human rights provisions overnight. In this case a step by step approach whereby human rights provisions are gradually introduced, is advised. In line with the UNGPs, banks could start with the loan agreements for high-risk sectors and clients. ${ }^{59}$ Banks are encouraged to seek cooperation with other banks and build on the growing market practice in the field of sanctions. This may enhance industry wide acceptance of human rights provisions in corporate lending and eventually, may contribute to improving the human rights of those potentially affected.

59 UNGP 17(b) and 24 and section IV(5) OECD Guidelines for Multinational Enterprises. 